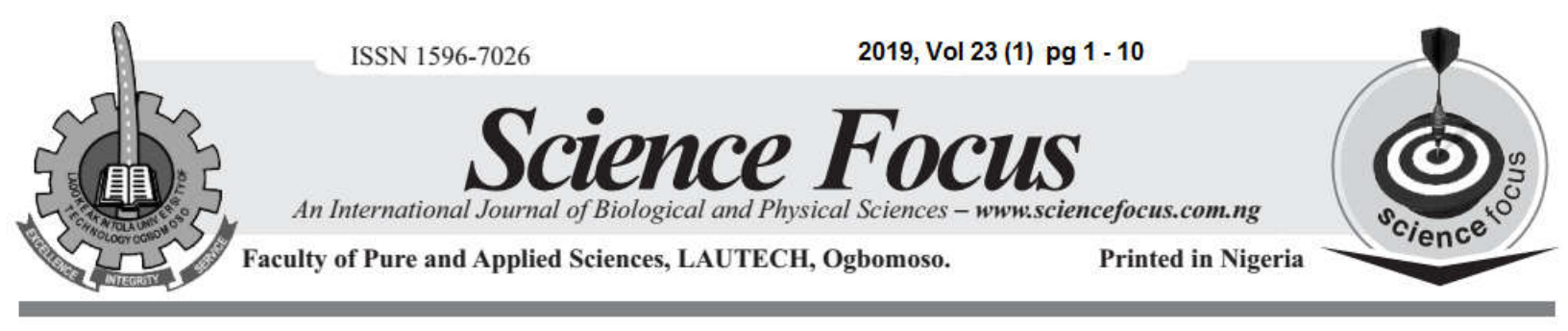

\title{
SYNTHESIS, CHARACTERIZATION AND ANTIMICROBIAL ACTIVITY OF SCHIFF BASE DERIVED FROM $O$-PHENYLENEDIAMINE AND ITS METAL (II) COMPLEXES
}

\author{
Lucky Ejikeme Didia and Temitope Elizabeth Olalekan*
}

Department of Chemistry, Faculty of Science, University of Ibadan, Oyo State, Nigeria

\section{Abstract}

The Schiff base $\left(\mathrm{LH}_{2}\right)$ was prepared by the equimolar reaction of o-phenylenediamine with $\mathrm{m}$ hydroxybenzaldehyde under reflux conditions. The metal (II) complexes were prepared by reacting the Schiff base with the metal (II) salts of Fe, Co, and Cu. NMR, IR, UV/Vis, CHN elemental analysis and magnetic moments were used to characterize the compounds. The formulas of the metal complexes were proposed using CHN analysis. In the metal (II) complexes the bands due to $v_{(O-H)}$ and $v_{(C-O)}$ were shifted to lower wavenumbers and the new medium band assigned to $v(M-O)$ indicated the coordination of the ligand to the metal ions through the phenolate oxygen. In the UV region, the intra ligand $\pi \rightarrow \pi^{*}$ (phenyl ring) and $n \rightarrow \pi^{*}(-C=N)$ transitions appeared as medium bands at 299 and $316 \mathrm{~nm}$ in the ligand. The metal (II) complexes also exhibit these bands as well as $d \rightarrow d$ transitions, which suggested tetrahedral coordination of the ligands to the metal ions. The magnetic moments obtained supported the tetrahedral geometries for the paramagnetic metal complexes. The inhibitory activity of the test compounds against Staphylococcus aureus and Pseudomonas aeruginosa observably improved upon chelation. The ligand and metal (II) complexes exhibited better antifungal (12-18 $\mathrm{mm})$ than antibacterial activity $(8-18 \mathrm{~mm})$.The positive controls, Gentamicin and Ketoconazole, showed diameters of zones of inhibition at 22-26 $\mathrm{mm}$ and $28 \mathrm{~mm}$ respectively.

Keywords: Schiff base, o-phenylenediamine, m-hydroxybenzaldehyde, metal complexes, antimicrobial, antifungal.

\section{Corresponding author.E-mail: topeolalekan11@yahoo.com.Tel: +2348035113509.}

\section{Introduction}

Schiff bases are organic compounds containing the azomethine group and have shown useful applications in biological, analytical, photochemical, electrochemical, theoretical and in structural studies (Adly et al, 2017; Olalekan et al, 2016; Patterson et al, 2014;Çakır and Biçer, 2010; RadeckaParyzek et al, 2007).

They are also used as catalysts in polymer and dye industries and have been used for immobilization of enzymes (Boghaei et al., 2008; Prashanthi, 2008). Schiff bases of 
salicylaldehyde or $o$-phenylenediamine with their metal complexes have been of interest due to their synthetic flexibility, rich coordination chemistry, stability, catalytic, and biological properties (Shebl et al, 2017; Fasina et al, 2014; Valarmathy and Subbalakshmi,2013; Budige, 2011;Gaballa et $a l, 2007)$. Studies on salophen-type Schiff bases with their metal complexes have been carried out, however, little investigations have been made on the analogous Schiff base formed by replacing salicylaldehyde $(o-$ hydroxybenzaldehyde) with $m$ hydroxybenzaldehyde. This research reports the synthesis, characterization and antimicrobial activity of the Schiff base formed from $o$-phenylenediamine and $m$ hydroxybenzaldehyde, and $\mathrm{Fe}(\mathrm{II}), \mathrm{Co}(\mathrm{II})$ and $\mathrm{Cu}$ (II) complexes of the Schiff base.

\section{Materials and Methods \\ Reagents and Instrumentation}

The analytical grade $o$-phenylenediamine and $m$-hydroxybenzaldehyde were supplied by Sigma Aldrich (Germany) and were used as obtained. Melting/decomposition temperatures were measured on Gallenkamp melting point apparatus. The infrared spectra were obtained on Perkin Elmer Infrared Spectrophotometer in the range 4000-400 $\mathrm{cm}^{-1}$.

The reflectance spectra were recorded on Perkin Elmer UV/Vis spectrophotometer in the ranges 400-190 nm and 900-400 nm for the UV and Visible absorptions respectively. The proton $\left({ }^{1} \mathrm{H}\right)$ and carbon $\left({ }^{13} \mathrm{C}\right) \mathrm{NMR}$ spectra for the ligand were obtained in DMSO- $\mathrm{d}_{6}$ on a Bruker avance $400 \mathrm{MHz}$ NMR spectrometer. The magnetic measurements were taken on Sherwood magnetic susceptibility Mark 1 balance. The compounds were screened for microbial inhibitory activity against Staphylococcus aureus, Bacillus subtilis, Pseudomonas aeruginosa, Escherichia coli, Aspergillus niger and Candida albicans (obtained from the Department of Pharmaceutical
Microbiology, University of Ibadan) using the agar diffusion technique.

\section{Synthesis of Schiff base ligand $\left(\mathrm{LH}_{2}\right)$}

Ethanol solution of $o$-Phenylenediamine (0.500 g, $4.60 \mathrm{mmol})$ was stirred on a hot plate magnetic stirrer. Ethanol solution containing 3-hydroxybenzaldehyde (1.242 g, $10.20 \mathrm{mmol}$ ) was gradually added into the solution in the round bottom flask. The solution was heated under reflux and after 3 $\mathrm{h}$, the product was formed as determined by thin layer chromatography. The orange product was allowed to cool, obtained by filtration, washed with ethanol and dried. The yield of the product was $1.027 \mathrm{~g}(70 \%)$.

\section{Synthesis of metal (II) complexes}

$\mathrm{LH}_{2}(0.100 \mathrm{~g}, 0.50 \mathrm{mmol})$ was dissolved in $10 \mathrm{~mL}$ distilled ethanol and stirred on hot plate. Separate ethanol solutions containing $0.25 \mathrm{mmol}$ of $\mathrm{FeSO}_{4} .7 \mathrm{H}_{2} \mathrm{O} \quad(0.080 \mathrm{~g})$, $\mathrm{CoCl}_{2} \cdot 6 \mathrm{H}_{2} \mathrm{O}(0.0684 \mathrm{~g}), \mathrm{CuCl}_{2} \cdot 2 \mathrm{H}_{2} \mathrm{O}(0.080$ g) and $\mathrm{Cu}\left(\mathrm{NO}_{3}\right)_{2} .3 \mathrm{H}_{2} \mathrm{O} \quad(0.070 \mathrm{~g})$ were respectively added to the ligand solution $(0.100 \mathrm{~g}, 0.50 \mathrm{mmol})$ and heated to reflux. Within a period of $3 \mathrm{~h}$, a colour change and precipitation was observed. After cooling at room temperature, the products were filtered and dried. The obtained masses (yield \%) of the products were $0.071 \mathrm{~g}(60 \%), 0.094 \mathrm{~g}$ $(66 \%), \quad 0.097 \mathrm{~g} \quad(54 \%)$ and $0.085 \mathrm{~g}$ $(58 \%)$ respectively.

\section{Antimicrobial assay procedure}

The agar well diffusion method was used to assess the in vitro antimicrobial activity of the compounds. The bacterial strains used were the Gram-positive Staphylococcus aureus and Bacillus subtilis, Gram-negative Pseudomonas aeruginosa and Escherichia Coli, and the fungi Aspergillus niger and Candida albicans. Gentamicin and Ketoconazole $(10 \mu \mathrm{g} / \mathrm{mL})$ were the positive controls for the antibacterial and antifungal tests respectively while $10 \%$ aqueous DMF 
was the negative control and the diluent. The agar and broth media, the bacterial strains and agar plates were prepared according to standard procedures (Sanders, 2012; Jorgensen and Turnidge, 2007). Solutions of test compounds in $10 \%$ aqueous DMF were prepared to obtain the concentration of 1 $\mathrm{mg} / \mathrm{mL}$. The wells were made on the agar plates with $8 \mathrm{~mm}$ sterile cork borer. In each well, $80 \mathrm{uL}$ of each test compound was added through the aid of a micro syringe, resulting into80 $\mu \mathrm{g}$ per well. The inoculated plates were incubated in the oven for 18-24 $\mathrm{h}$ at $37^{\circ} \mathrm{C}$ (bacteria) and $48 \mathrm{~h}$ at $30^{\circ} \mathrm{C}$ (fungi), thereafter the diameters of zones of inhibition zones were determined. The antimicrobial tests were carried out in duplicates following a similar procedure.

\section{Results and Discussion}

The ligand $\left(\mathrm{LH}_{2}\right)$ and metal (II) complexes were derived in 54-70\% yields. Their analytical and physical data are presented in Table 1.

Table 1: Analytical data of Schiff base and metal (II) complexes

\begin{tabular}{|c|c|c|c|c|c|c|c|}
\hline \multirow[t]{2}{*}{ Compounds } & \multirow{2}{*}{$\begin{array}{l}\text { Formula } \\
\text { weight }\end{array}$} & \multirow{2}{*}{$\begin{array}{l}\text { Melting } \\
\text { point }\left({ }^{\circ} \mathrm{C}\right)\end{array}$} & \multirow[t]{2}{*}{$\%$ Yield } & \multicolumn{2}{|c|}{ Calculated (Found) } & \multirow{2}{*}{$\begin{array}{l}\% \\
\mathrm{~N}\end{array}$} & \multirow[t]{2}{*}{$\mu_{\mathrm{eff}}$} \\
\hline & & & & $\mathrm{C}$ & $\mathrm{H}$ & & \\
\hline $\mathrm{LH}_{2}$ & 316.38 & $230-232$ & 70 & $\begin{array}{c}75.45 \\
(75.05)\end{array}$ & $\begin{array}{l}5.70 \\
(5.01)\end{array}$ & $\begin{array}{l}8.80 \\
(8.79)\end{array}$ & --- \\
\hline$\left[\mathrm{Fe}(\mathrm{LH})_{2}\right]$ & 686.55 & $214-216$ & 60 & $\begin{array}{l}69.98 \\
(69.67)\end{array}$ & $\begin{array}{l}4.40 \\
(5.31)\end{array}$ & $\begin{array}{l}8.16 \\
(8.21)\end{array}$ & 5.0 \\
\hline$\left[(\mathrm{CoLHCl})_{2}\right] \cdot 2 \mathrm{H}_{2} \mathrm{O}$ & 855.50 & $120-122$ & 66 & $\begin{array}{l}56.16 \\
(55.70)\end{array}$ & $\begin{array}{l}4.01 \\
(4.72)\end{array}$ & $\begin{array}{l}6.55 \\
(7.22)\end{array}$ & 4.5 \\
\hline$\left[\mathrm{Cu}(\mathrm{LH})_{2}\right] \cdot 3 \mathrm{H}_{2} \mathrm{O}$ & 748.30 & $146-148$ & 54 & $\begin{array}{l}64.20 \\
(64.41)\end{array}$ & $\begin{array}{l}4.85 \\
(4.33)\end{array}$ & $\begin{array}{l}7.49 \\
(7.45)\end{array}$ & 1.6 \\
\hline$\left[\left(\mathrm{CuLH}\left(\mathrm{NO}_{3}\right)\right)_{2}\right]$ & 881.80 & $160-162$ & 58 & $\begin{array}{l}54.48 \\
(54.27)\end{array}$ & $\begin{array}{l}3.43 \\
(3.69) \\
\end{array}$ & $\begin{array}{l}9.53 \\
(9.31) \\
\end{array}$ & 2.0 \\
\hline
\end{tabular}

The colour of the ligand was orange while the metal(II) complexes showed varying colours of yellow (Fe(II)), green (Co(II)) and brown $(\mathrm{Cu}(\mathrm{II}))$. The melting point of $\mathrm{LH}_{2}$ was at $230-232^{\circ} \mathrm{C}$ while the metal(II) complexes melted in the range $120-216^{\circ} \mathrm{C}$. The compounds were generally soluble in DMF, but on heating they were soluble in DMSO. CHN elemental analysis data were well correlated with the proposed formula weights of the compounds.

\section{The NMR Spectra for $\mathrm{LH}_{2}$}

The proton $\left({ }^{1} \mathrm{H}\right)$ and carbon $\left({ }^{13} \mathrm{C}\right) \mathrm{NMR}$ spectra for $\mathrm{LH}_{2}$ are shown in Figures 1 and 2 with following absorptions: ${ }^{1} \mathrm{H}$ NMR (400 $\left.\mathrm{MHz}, \mathrm{DMSO}-\mathrm{d}_{6}\right): \delta=5.48(s, 2 \mathrm{H}, \mathrm{OH})$, 6.37-7.72 ( $m, 12 \mathrm{H}$, aromatic protons $), 9.41$, $(\mathrm{s}, 1 \mathrm{H}, \mathrm{CH}=\mathrm{N}), 9.78 \mathrm{ppm}(\mathrm{s}, 1 \mathrm{H}, \mathrm{CH}=\mathrm{N})$.
111.57-153.76 (aromatic carbons), 157.99

$(\mathrm{CH}=\mathrm{N}), 158.17(\mathrm{CH}=\mathrm{N})$ ppm. The broad singlet peak at 5.48 ppm was assigned to the phenolic protons. The phenolic protons in the analogous 'salophen' Schiff base have shown absorptions in the region $12.94 \mathrm{ppm}$ (Ntukidem et al, 2018). The reduced frequency observed in the Schiff base reported here could be as a result of hydrogen bonding between the hydroxyl groups and the imine nitrogen atoms. The intense multiple peaks of the aromatic protons were seen in the range 6.37-7.72 ppm. The resonant signals of the azomethine protons were observed at 9.41 and $9.78 \mathrm{ppm}$ as singlet peaks. ${ }^{13} \mathrm{C}$ NMR spectrum showed the absorptions of aromatic carbons between 111.57 and $153.76 \mathrm{ppm}$. The azomethine carbon absorption was seen at $158.17 \mathrm{ppm}$. 


\section{Infrared Spectra}

The important and relevant bands in the infrared spectra of $\mathrm{LH}_{2}$ and metal complexes are recorded on Table 2.

Table 2: Important infrared spectra bands in Schiff base and metal(II) complexes (in $\mathrm{cm}^{-1}$ )

\begin{tabular}{lcclcc}
\hline Compounds & $\mathrm{O}-\mathrm{H}$ & $\mathrm{H}-\mathrm{C}=\mathrm{N}$ & $\mathrm{C}=\mathrm{C}$ C $=\mathrm{N}$ & $\mathrm{C}-\mathrm{O}$ & $\mathrm{M}-\mathrm{O}$ \\
\hline $\mathrm{LH}_{2}$ & $3475,3257,1336,622$ & 2944,287115971584 & 1258 & \\
{$\left[\mathrm{Fe}(\mathrm{LH})_{2}\right]$} & $3398,3187,1336,621$ & 2944,287215981583 & 1250 & 372 \\
{$\left[(\mathrm{CoLHCl})_{2}\right] .2 \mathrm{H}_{2} \mathrm{O}$} & $3551,3192,1335,619$ & 2943,287015991584 & 1226 & 369 \\
{$\left[\mathrm{Cu}(\mathrm{LH})_{2}\right] .3 \mathrm{H}_{2} \mathrm{O}$} & $3450,3228,1333,619$ & 2944,286715951587 & 1225 & 367 \\
{$\left[\left(\mathrm{CuLH}\left(\mathrm{NO}_{3}\right)\right)_{2}\right]$} & $3413,3100,1333,620$ & 2940,286515991589 & 1234 & 360 \\
\hline
\end{tabular}

In the ligand, the broad bands around 3476 and $3257 \mathrm{~cm}^{-1}$ were assigned to aromatic $v_{(\mathrm{O}-\mathrm{H})}$ while the $\delta_{(\mathrm{O}-\mathrm{H})}$ vibrations appeared as medium bands at 1336 and $622 \mathrm{~cm}^{-1}$ (Sakar, 2009; Olalekan et al, 2015; Smith, 1998). The frequency of the absorption band at $3257 \mathrm{~cm}^{-1}$ was lowered to the range $3228-$ $3100 \mathrm{~cm}^{-1}$ in the

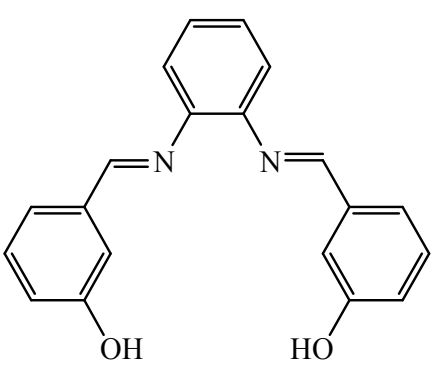

$\mathbf{L H}_{2}$



[Fe(LH)2)]

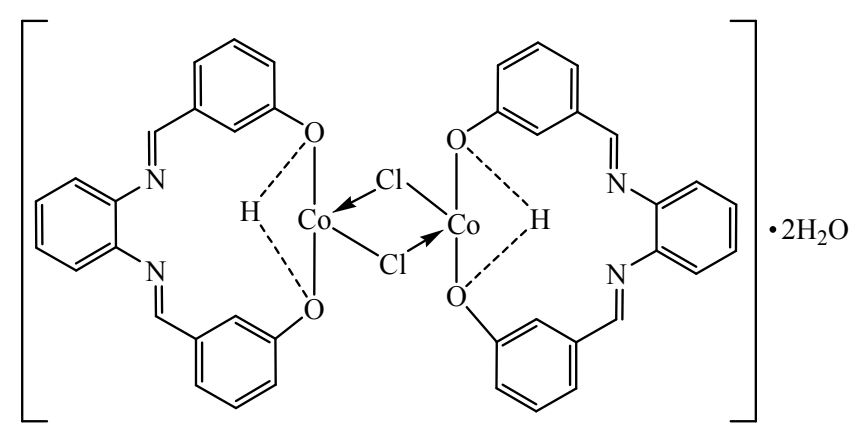

[(CoLHCl $\left.)_{2}\right]$

complexes; this indicated the participation of the phenol oxygen $(\mathrm{C}-\mathrm{O})$ in chelation. The bending vibrational modes were however unaffected, being found in the ranges 13361333 and $621-619 \mathrm{~cm}^{-1}$. This would imply the ligand was binding as a bidentate anionic ligand (Figure 3). 


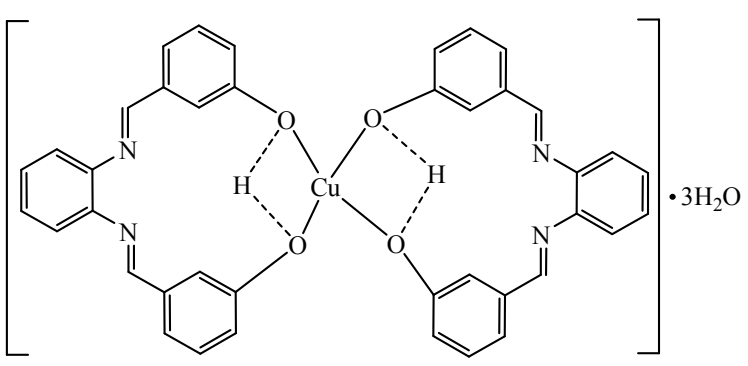

$\left.\left[\mathrm{Cu}(\mathrm{LH})_{2}\right)\right]$

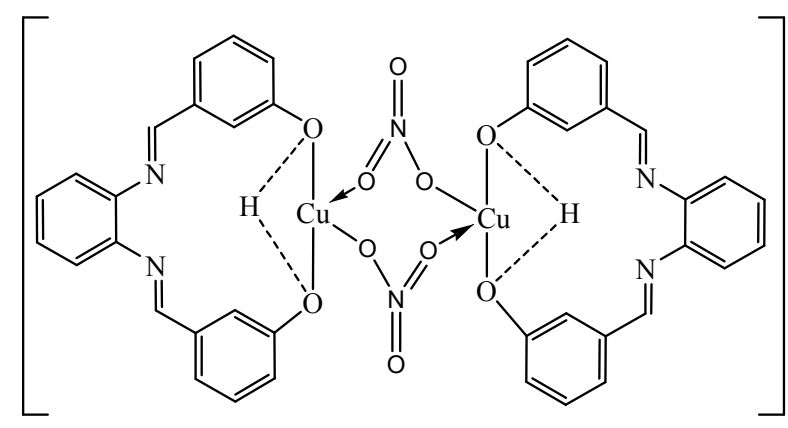

$\left[\left(\mathrm{CuLH}\left(\mathrm{NO}_{3}\right)\right)_{2}\right]$

Figure 3: The diagram of the ligand and the proposed structures of metal(II) complexes

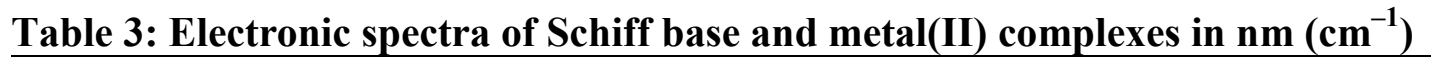

\begin{tabular}{lclc}
\hline Compounds & $\pi \rightarrow \pi^{*}$ & \multicolumn{1}{c}{$n \rightarrow \pi^{*}$} & $d \rightarrow d$ \\
& & & --- \\
$\mathrm{LH}_{2}$ & $296(33784)$ & $325(30769)$ & $\left.-\mathrm{Cm}^{-1}\right)$ \\
{$\left[\mathrm{Fe}(\mathrm{LH})_{2}\right]$} & $298(33557)$ & $316(31645)$ & $566\left(17668 \mathrm{~cm}^{-1}\right)$ \\
{$\left[(\mathrm{CoLHCl})_{2}\right] .2 \mathrm{H}_{2} \mathrm{O}$} & $296(33784)$ & $321(31153)$ & $615(16260), 682(14663)$ \\
{$\left[\mathrm{Cu}(\mathrm{LH})_{2}\right] .3 \mathrm{H}_{2} \mathrm{O}$} & $293(34130)$ & $329(30395)$ & $440(22727)$ \\
{$\left[\left(\mathrm{CuLH}\left(\mathrm{NO}_{3}\right)\right)_{2}\right]$} & $296(33784)$ & $330(30303)$ & $420(23810)$ \\
\hline
\end{tabular}

The strong sharp bands at 3551 and 3450 $\mathrm{cm}^{-1}$ corresponded to the frequencies of lattice (uncoordinated) molecules in the spectra of $\left[(\mathrm{CoLHCl})_{2}\right] \cdot 2 \mathrm{H}_{2} \mathrm{O}$ and $\left[\mathrm{Cu}(\mathrm{LH})_{2}\right] \cdot 3 \mathrm{H}_{2} \mathrm{O}$ respectively (Raman et al, 2001). Two bands found in the regions 2944 $2943 \mathrm{~cm}^{-1}$ and $2872-2866 \mathrm{~cm}^{-1}$ were respectively attributed to the azomethine $v_{\text {asy }}$ $(\mathrm{C}-\mathrm{H})$ and $v_{\text {sym }}(\mathrm{C}-\mathrm{H})$ in the ligand and metal complexes. The phenyl ring stretching vibration was also observed between $1599 \mathrm{~cm}^{-1}$ and $\quad 1597 \mathrm{~cm}^{-1}$ in the compounds. The band due to azomethine $v(\mathrm{C}=\mathrm{N})$ was seen at $1584 \mathrm{~cm}^{-1}$ in the ligand. There was no change in the frequency of this band in the metal(II) complexes, being found around 1589-1583 $\mathrm{cm}^{-1}$, and this has suggested that there was no coordination to the metal ions through the azomethine nitrogen. $v_{(\mathrm{C}-0) \text { Was observed at } 1258 \mathrm{~cm}^{-1} \text { in }}$ the Schiff base and was lowered to frequencies in the range $1250-1225 \mathrm{~cm}^{-1}$ in the metal(II) complexes, demonstrating that phenol oxygen was coordinated to the metal(II) ions.
The strong nitrate bands observed in the spectrum of $\left[\left(\mathrm{CuLH}\left(\mathrm{NO}_{3}\right)_{2}\right]\right.$ at 1420,1384 and $1283 \mathrm{~cm}^{-1}$ were assigned to $v_{4}, v_{3}$ and $v_{1}$ of the coordinated nitrate ion respectively (Nakamoto,2006, 1977; Lever et al, 1971). The new band in the low frequency region $372-360 \mathrm{~cm}^{-1}$ was attributed to metal to oxygen vibrational stretches.

\section{Electronic spectra and magnetic moments}

The reflectance spectra of the solid compounds were obtained and the data was recorded in Table 3. For the Schiff base, two bands were found in the UV region at 296 $\mathrm{nm}$ and $325 \mathrm{~nm}$ which have been assigned to transitions $\pi \rightarrow \pi^{*}$ (phenyl ring) and $n \rightarrow \pi^{*}$ ($\mathrm{H}-\mathrm{C}=\mathrm{N}$ ). These are intra ligand transitions and are due to the presence of lone electron pair on the nitrogen atom and double bonds in $\mathrm{C}=\mathrm{C}$ and $\mathrm{C}=\mathrm{N}$ groups in the ligand structure.

These ligand bands were also seen in the spectra of the complexes in the ranges 293- 
298 and $316-330 \mathrm{~nm}$. In the visible region, $\left[\mathrm{Fe}(\mathrm{LH})_{2}\right]$ complex showed a band at 566 $\mathrm{nm}$. A single absorption band around 25000 $\mathrm{nm}\left(4000 \mathrm{~cm}^{-1}\right)$ expected for ${ }^{5} \mathrm{E} \rightarrow{ }^{5} \mathrm{~T}_{2}$ transition in a tetrahedral geometry was absent. The magnetic moment of 5.0 BM lies in the range 5.0-5.4 $\mathrm{BM}$ reported for tetrahedral complexes (Greenwood and Earnshaw, 1997). [(CoLHCl $\left.)_{2}\right] \cdot 2 \mathrm{H}_{2} \mathrm{O}$ showed two bands at $615 \mathrm{~nm}\left(16260 \mathrm{~cm}^{-1}\right)$ and $682 \mathrm{~nm}\left(14663 \mathrm{~cm}^{-1}\right)$ assigned to $\mathrm{A}_{2}(\mathrm{~F}) \rightarrow{ }^{4} \mathrm{~T}_{2}(\mathrm{P})\left(\mathrm{v}_{3}\right)$ and $\mathrm{A} \rightarrow{ }^{4} \mathrm{~T}(\mathrm{~F})\left(\mathrm{v}_{1}\right)$

respectively in a tetrahedral coordination.

The magnetic moment of 4.5 BM corroborates the suggested tetrahedral geometry for a Co (II) complex with high spind $^{7}$ configuration (Greenwood and Earnshaw, 1997). The complexes $\left[\mathrm{Cu}(\mathrm{LH})_{2}\right] \cdot 3 \mathrm{H}_{2} \mathrm{O}$ and $\left[\left(\mathrm{CuLH}\left(\mathrm{NO}_{3}\right)\right)_{2}\right]$ exhibited bands at $440 \mathrm{~nm}\left(22727 \mathrm{~cm}^{-1}\right)$ and
$420 \mathrm{~nm}\left(23810 \mathrm{~cm}^{-1}\right)$ respectively and were attributed to ${ }^{2} \mathrm{~T} \rightarrow{ }^{2} \mathrm{E}$ absorption in a tetrahedral arrangement.

The magnetic moment of $1.6 \mathrm{BM}$ for $\left[\mathrm{Cu}(\mathrm{LH})_{2}\right] \cdot 3 \mathrm{H}_{2} \mathrm{O}$ suggested that the complex is not magnetically dilute. The magnetic moment of $\left[\left(\mathrm{CuLH}\left(\mathrm{NO}_{3}\right)\right)_{2}\right]$ was $2.0 \mathrm{BM}$ and falls within the range expected for tetrahedral $\mathrm{Cu}(\mathrm{II})$ complexes (Greenwood and Earnshaw, 1997).

\section{Antimicrobial assay}

The agar dilution method was used to assess the antimicrobial potential of the synthesized compounds against four bacterial and two fungal strains and the diameters of inhibition zones $(\mathrm{mm})$ have been recorded in Table 4.

Table 4: The diameter of inhibition zones by the ligands and metal(II) complexes (mm)

\begin{tabular}{lcccccc}
\hline \multicolumn{1}{c}{ Compounds } & S. aureus & B. subtilis & P. Aeruginosa & E. coli & A. niger \\
\hline $\mathrm{LH}_{2}$ & 8 & 10 & 8 & 18 & 18 & 18 \\
{$\left[\mathrm{Fe}(\mathrm{LH})_{2}\right]$} & 10 & 10 & 12 & 14 & 12 & 18 \\
{$\left[\mathrm{Co}(\mathrm{LHCl})_{2}\right]$} & 12 & 16 & 12 & 12 & 18 & 18 \\
{$\left[\mathrm{Cu}(\mathrm{LH})_{2}\right]$} & 10 & 16 & 10 & 8 & 18 & 18 \\
{$\left[\left(\mathrm{CuLH}\left(\mathrm{NO}_{3}\right)_{2}\right]\right.$} & 10 & 14 & 10 & 12 & 20 & 16 \\
Gentamicin & 20 & 26 & 22 & 20 & NA & NA \\
Ketoconazole & NA & NA & NA & NA & 28 & 28 \\
\hline
\end{tabular}

Not applicable NA

The ligand demonstrated a better inhibitory activity against $E$. coli $(18 \mathrm{~mm})$ than the metal complexes $(8-14 \mathrm{~mm})$.The ligand, however, could not inhibit the growth of $S$. aureus and $P$. aeruginosa while the metal complexes improved upon this with inhibition zones in the range $10-18 \mathrm{~mm}$.

The antifungal activity of the ligand and metal complexes against A. niger and $C$. albicans was recorded by inhibition zones of $12-20 \mathrm{~mm}$. These synthesized compounds showed promising antifungal potential. The inhibitory zones by the positive controls were measured as $20-26 \mathrm{~mm}$ (Gentamicin) and $28 \mathrm{~mm}$ (Ketoconazole).

\section{Conclusion}

The Schiff base ligand $\left(\mathrm{LH}_{2}\right)$ was derived from the reaction of $o$-phenylenediamine with $m$-hydroxybenzaldehyde. Its $\mathrm{Fe}$ (II), $\mathrm{Co}(\mathrm{II})$ and $\mathrm{Cu}(\mathrm{II}))$ complexes were derived from 1:1 stoichiometric reaction between the metal salts and the ligand.

The obtained analytical and spectral data was useful in characterization of the compounds - the ligand and the complexes. It was found that the ligand coordinated to 
the metal ions through the phenol oxygen as a bidentate anionic ligand.

The electronic spectra and magnetic moment have suggested a tetrahedral geometry for the complexes. The antimicrobial screening revealed that the ligands and metal(II) complexes demonstrated better antifungal activity than antibacterial activity, and could be promising antifungal agents. Based on the available instrumental techniques employed, the proposed structures of the compounds are shown in Figure 3.

\section{Disclosure of any funding to the study}

This research did not receive any specific grant from funding agencies in the public, commercial, or not-for-profit sectors.

\section{Disclosure of any conflict of interest}

The authors declare there are no conflicts of interests.

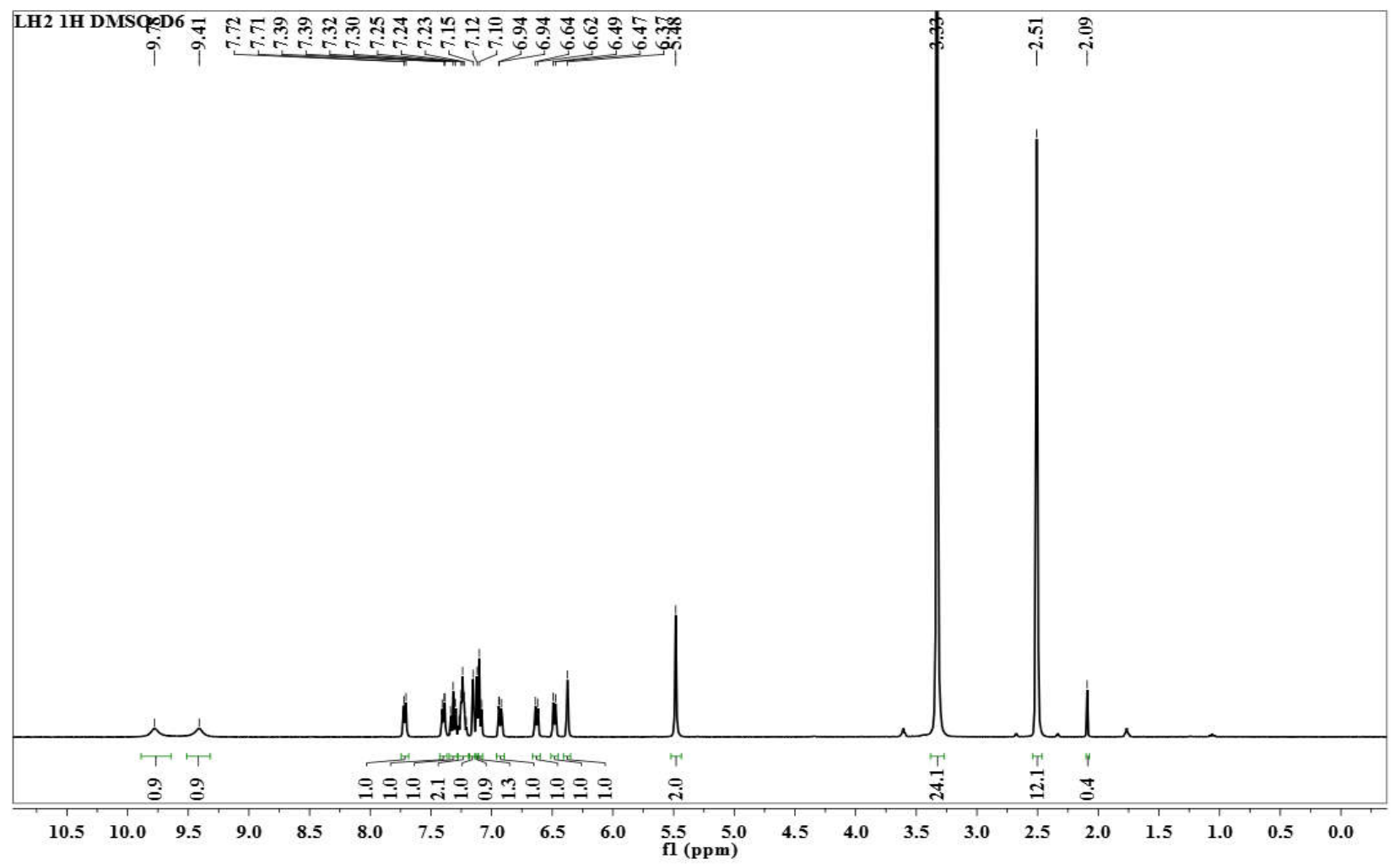

Figure 1: ${ }^{1} \mathrm{H}$ NMR spectrum of Schiff base $\mathrm{LH}_{2}\left(400 \mathrm{MHz}, \mathrm{DMSO}-\mathrm{d}_{6}\right)$ 


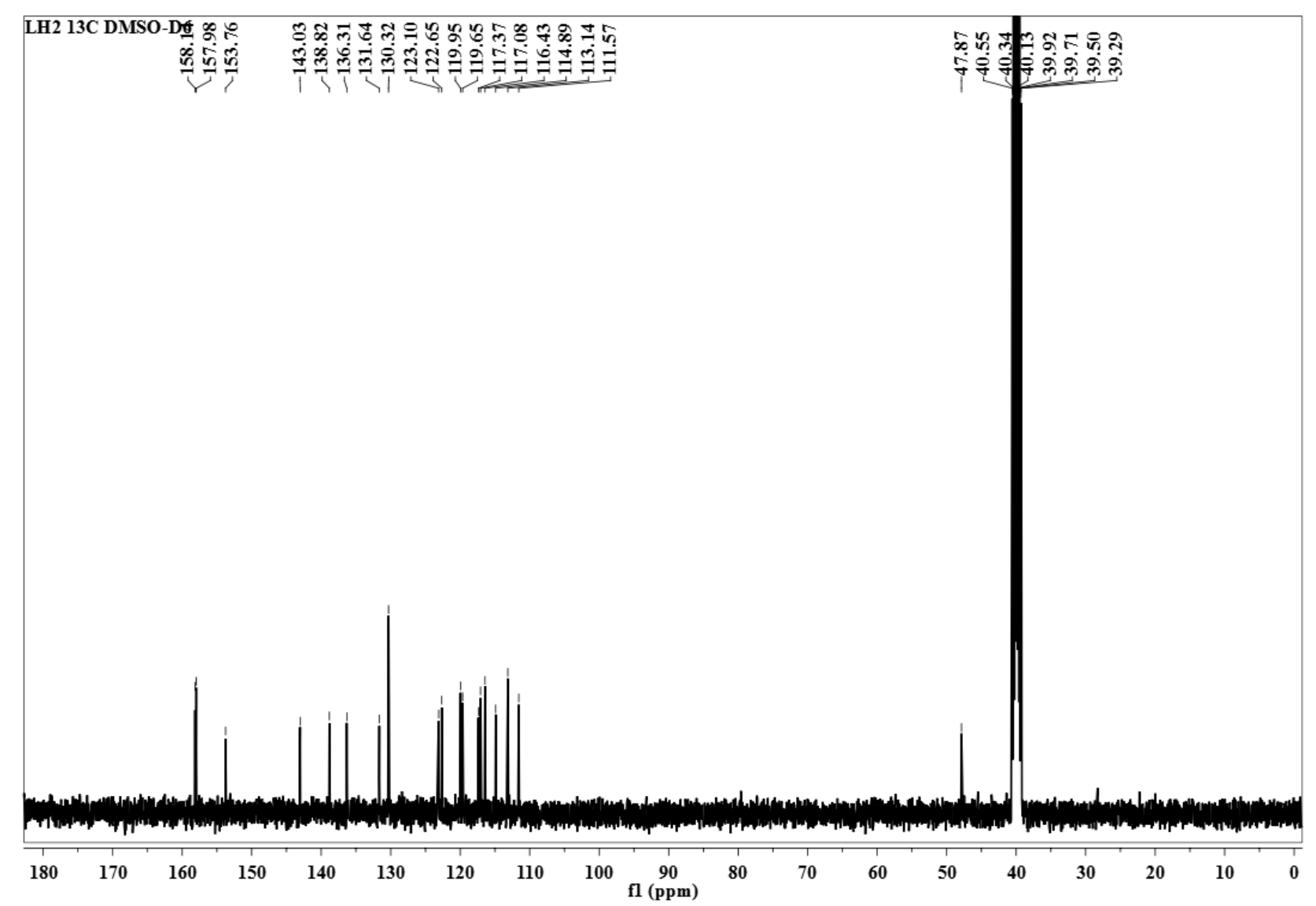

Figure 2: ${ }^{13} \mathrm{C}$ NMR spectrum of Schiff base $\mathrm{LH}_{2}\left(400 \mathrm{MHz}, \mathrm{DMSO}-\mathrm{d}_{6}\right)$

\section{References}

Adly, O.M.I., Shebl, M., El-Shafiy, H.F., Khalil, S.M.E., Taha, A., Mahdi, M.A.N. (2017). Synthesis, spectroscopic characterization, antimicrobial and antitumor studies of mono-, bi- and tri-nuclear metal complexes of a new Schiff base ligand derivedfrom $o$-acetoacetyl phenol. Journal of Molecular Structure, 1150, 507-522.

Boghaei, D.M., Askarizadeh, E., Bezaatpour, A. (2008). Synthesis, characterization, spectroscopic and thermodynamic studies of charge transfer interaction of a new watersoluble cobalt(II) Schiff base complex with imidazole derivatives. Spectrochimica Acta Part A: Molecular and Biomolecular Spectroscopy69, 624-628.

Budige, G., Puchakayala, M.R., Kongara, S.R., Hu, A., Vadde, R. (2011). Synthesis, characterization and biological evaluation of mononuclear $\mathrm{Co}(\mathrm{II}), \mathrm{Ni}(\mathrm{II}), \mathrm{Cu}(\mathrm{II})$ and $\mathrm{Pd}(\mathrm{II})$ complexes with New $\mathrm{N}_{2} \mathrm{O}_{2}$ Schiff base ligands. Chemical and Pharmaceutical Bulletin 59, 166-171.

Çakır S., Biçer E. (2010). Synthesis, spectroscopic and electrochemical characteristics of a novel Schiff-base from saccharin and tryptophan. Journal of the Iranian Chemical Society 7, 394-404.

Fasina, T.M., Ogundele, O.O., Ayeni, I. (2014). Synthesis and biological properties of $\mathrm{N}_{2} \mathrm{O}_{2}$ Schiff bases derived from $O$ phenylenediamine and substituted salicylaldehydes. Journal of Chemical and Pharmaceutical Research 6, 816-819. 
Gaballa, S.A., Mohsen, S.A., Atiat, S.B., Said, M.T. (2007). Synthesis, characterization and biological activity of some platinum(II) complexes with Schiff bases derived from salicylaldehyde, 2furaldehyde and phenylenediamine. Spectrochimica Acta Part A: Molecular and Biomolecular Spectroscopy 67, 114-121.

Greenwood, N.N., Earnshaw, A. (1997). Chemistry of the Elements, second ed. Butterworth-Heinemann, UK, pp.1092, 1130-1133, 1193-1194.

Jorgensen, J.H., Turnidge, J.D. (2007). Susceptibility test methods: dilution and disk diffusion methods, in:Murray, P.R., Baron, E.J., Jorgensen, J.H., Landry, M.L., Pfaller, M.A. (Eds.), Manual of clinical microbiology, American Society for Microbiology, Washington D.C., 9th ed., Volume 1, pp. 1152-1172.

Lever, A.B.P., Mantovani, E., Ramaswamy, B.S. (1971). Infrared combination frequencies in coordination complexes containing nitrate groups in various coordination environments. A probe for the metal-nitrate interaction. Canadian Journal of Chemistry 49, 1957-1964.

Nakamoto, K. (2006). Infrared and Raman Spectra of Inorganic and Coordination Compounds.Handbook of Vibrational Spectroscopy. John Wiley \& Sons,pp.18721892.

Nakamoto, K. (1977). Infrared and Raman Spectra of Inorganic and Coordination Compounds. Part A: Theory and Applications in Inorganic Chemistry; Part B: Application in Coordination, Organometallic, and Bioinorganic Chemistry, fifth ed., pp 87-98.

Ntukidem, E.N., Olalekan, T.E., Ayeni, F.A. (2018). Synthesis, characterization and antimicrobial studies of $o$-phenylenediamine Schiff base, Ni(II), $\mathrm{Cu}(\mathrm{II}), \mathrm{Zn}(\mathrm{II})$ complexes and $\mathrm{Cu}$ (II) adduct. Journal of Science Research (in press).

Olalekan, T.E., Ogunlaja, A.S., Van Brecht, B., Watkins, G.M. (2016). Spectroscopic, structural and theoretical studies of copper(II) complexes of tridentate NOS Schiff bases. Journal of Molecular Structure 1122, 72-79.

Olalekan, T.E., Adejoro, I.A., VanBrecht B., Watkins, G.M. (2015). Crystal structures, spectroscopic and theoretical study of novel Schiff bases of 2-(methylthiomethyl) anilines. Spectrochimica Acta Part A: Molecular and Biomolecular Spectroscopy139, 385-395.

Patterson, E., Miller, J.J., Miles, B.A., Stewart, E.L., Melanson, J-M.E.J., Vogels, C.M., Cockshutt, A.M., Decken, A., Morin Jr., P., Westcott, S.A. (2014). Synthesis, characterization and anticancer properties of (salicylaldiminato)platinum(II) complexes. Inorganica Chimica Acta 415, 88-94.

Prashanthi, Y., Kiranmai, K., Subhashini, N.J.P., Shivaraj (2008). Synthesis, potentiometric and antimicrobial studies on metal complexes of isoxazole Schiff bases. Spectrochimica Acta Part A: Molecular and Biomolecular Spectroscopy70, 30-35.

Radecka-Paryzek, W., PospiesznaMarkiewicz, I., Kubicki, M. (2007). Selfassembled two-dimensional salicylaldimine lanthanum(III) nitrate coordination polymer. Inorganica Chimica Acta360, 488-496.

Raman, N., Raja, Y.P., Kulandaisamy, A. (2001). Synthesis and characterisation of $\mathrm{Cu}(\mathrm{II}), \mathrm{Ni}(\mathrm{II}), \mathrm{Mn}(\mathrm{II}), \mathrm{Zn}(\mathrm{II})$ and $\mathrm{VO}(\mathrm{II})$ Schiff base complexes derived from $o$ phenylenediamine and acetoacetanilide. Journal of Chemical Sciences 113,183-189.

Sanders, (E.R. 2012). Aseptic laboratory techniques: plating methods. Journal of Visualized Experiments 63, e3064. DOI: 10.3791/3064. 
Sarkar, S., Dhara, P.K., Nwthaji, M., Chattopadhay, P. (2009). Copper(II) complexes of tridentate SNO ligands: synthesis, characterization and crystal structure. Journal of Coordination Chemistry 62, 817-824.

Shebl, M., Adly, O.M.I., El-Shafiy, H.F., Khalil, S.M.E., Taha, A., Mahdi, M.A.N. (2017). Structural variety of mono- and binuclear transition metal complexes of 3[(2- hydroxy-benzylidene)-hydrazono]-1-(2hydroxyphenyl)-butan-1-one: Synthesis, spectral, thermal, molecular modeling, antimicrobial and antitumor studies. Journal of Molecular Structure 1134, 649-660.

Smith, B.C. (1998). Infrared Spectral Interpretation: A Systematic Approach, first ed. CRC, Cleveland.

Valarmathy, G., Subbalakshmi, R. (2013).Synthesis, characterization and antimicrobial Screening of $\mathrm{Co}(\mathrm{II}), \mathrm{Ni}(\mathrm{II})$, $\mathrm{Cu}(\mathrm{II}), \mathrm{Mn}$ (II) and $\mathrm{Zn}$ (II) complexes with Schiff base derived from 2sulphanilamidopyridine and 2-hydroxy-3methoxybenzaldehyde. Asian Journal of Chemistry 25, 2077-2079. 